\title{
Physico-Chemical Characterization and Fatty Acid Profile of the Acrocomia emensis (Arecaceae) Seed Oil
}

\author{
Déborah Santos Neiva ${ }^{1}$, Juliana Almeida Rocha ${ }^{1}$, Afrânio Farias de Melo Junior ${ }^{1}$, Dario Alves Oliveira ${ }^{1}$, \\ Murilo Malveira Brandão ${ }^{1}$, Vany Perpetua Ferraz ${ }^{2}$, Vanessa de Andrade Royo ${ }^{1} \&$ Elytania Veiga Menezes ${ }^{1}$ \\ ${ }^{1}$ Laboratory Bioprospecting and Genetic Resources and Laboratory of Natural Products, State University of \\ Montes Claros, Campus Darcy Ribeiro, Vila Mauriceia, Montes Claros, MG, Brazil \\ ${ }^{2}$ Laboratory of Chromatograph of Institute of Exact Sciences, Chemistry Department, Federal University of \\ Minas Gerais, Pampulha, Belo Horizonte, MG, Brazil \\ Correspondence: Vanessa de Andrade Royo, Laboratory Bioprospecting and Genetic Resources and Laboratory \\ of Natural Products, State University of Montes Claros, Campus Darcy Ribeiro, Vila Mauriceia, CEP 39401-089, \\ Montes Claros, MG, Brazil. Tel: 55-383-229-8342. E-mail: vanroyo31@gmail.com
}

Received: October 28, 2017

Accepted: November 27, 2017

Online Published: December 15, 2017

doi:10.5539/jas.v10n1p264

URL: https://doi.org/10.5539/jas.v10n1p264

The research is financed by Petrobrás.

\begin{abstract}
In Brazil there are several oleaginous plants, with the potential to supply oil as raw material for various types of industries (cosmetic, pharmaceutical, energy, among others), among them we have the Acrocomia emensis (Arecaceae) known as tucum rasteiro. The objective of this work was to realize: extraction of the oil of the almonds using two types of cold mechanical press (walrus type and manual hydraulic type of 15 tons), physical-chemical analyzes (acidity index, peroxides, refraction, moisture and volatile material, ash, viscosity and density at $25^{\circ} \mathrm{C}$ ) and fatty acid profile of the oil extracted from almonds of $A$. emensis from three localities in the northern state of Minas Gerais, Brazil (Bonito de Minas, Brasília de Minas and Montes Claros). The values of the physical-chemical indexes varied among the samples from the different locations. Extraction using walrus type press provided higher yield. The fatty acids of the oils of the three origins were: caprylic, capric, lauric, myristic, palmitic, stearic, oleic and linoleic. The majority in the three samples were the lauric acid.
\end{abstract}

Keywords: almonds, lauric acid, oleaginous, tucum

\section{Introduction}

Acrocomia emensis (Arecaceae), popularly known as tucum rasteiro, is a sub-shrubpalm characteristic of Cerrado lato sensu, found in the states of Mato Grosso do Sul, Goiás, Minas Gerais, Paraná and São Paulo, Brazil. It has globose fruits, with leathery epicarp of yellowish-green color, mesocarpo fleshy and immersed in short fibers strongly adhered to the endocarp. This one presents black coloration, $2 \mathrm{~mm}$ thick and contains a single seed. Regional fauna such as armadillos, possums and small rodents consume the fruits (Lorenzi, 2010).

The potentialities of the A. emensis fruits are still unclear. However, in Brazil palm trees, in general, stand out for the use of products and by-products. Being these used in the food, cosmetics and energy industries. There are studies of physico-chemical parameters of oils of some species of the family Arecaceae that demonstrate the possibility of the use in the production of biodiesel. Some exemples are Buriti (Mauritia flexuosa), Palma (Elaeis guineensis), Tucumã (Astrocaryum aculeatum), Macaúba (Acrocomia aculeata) and Jerivá (Syagrus romanzoffiana) (Barbosa et al., 2009; Cesar et al., 2015; Esteban et al., 2012; Coimbra \& Jorge, 2012)

Due to the few existing works on this species, studies on the oil potential of the fruits of this palm are necessary. Because it is important to look for new species that produce good quality oil for the production of biotechnological products such as biodiesel, since currently the production of this fuel occurs using as input mainly the soybean oil that is also used in food (No, 2011).

From the analysis of physicochemical parameters of the oil is possible to identify if it presents suitable characteristics to be used in the production of biodiesel. The verification of different extractive methods to obtain 
the oil is important as a way to select the best procedures, promoting better use of the raw material (No, 2011; Manfio et al., 2011).

Thus, the objectives of the present work were to evaluate two types of press: walrus and hydraulic press, physical-chemical characteristics and to identify the fatty acids, of the A. emensis fruits of three localities in the North of Minas Gerais, Brazil.

\section{Method}

\subsection{Plant Material}

The fruits were collected in three locations in the North of Minas Gerais: Cordinates (UTM): Bonito de Minas (23 K 508650 8315987), Brasília de Minas (23 K 569414 8206247) and Montes Claros (23 K 6008998169206 ) (Figure 1). In each locality, 50 individuals were studied, from which a bunch of fruits were collected. Collection took place in February 2015, a sample was deposited on the form of exsicata in the Herbarium of the State University of Montes Claros Voucher 4.362. In total, 2,083 fruits were collected, Bonito de Minas (614), Brasília de Minas (726) and Montes Claros (743). After collection, the fruits were taken to the Laboratory of Bioprospecting and Genetic Resources at the State University of Montes Claros. It was made fruits asepsis and storage in plastic trays at $17^{\circ} \mathrm{C}\left( \pm 2{ }^{\circ} \mathrm{C}\right)$ until the beginning of the analysis.

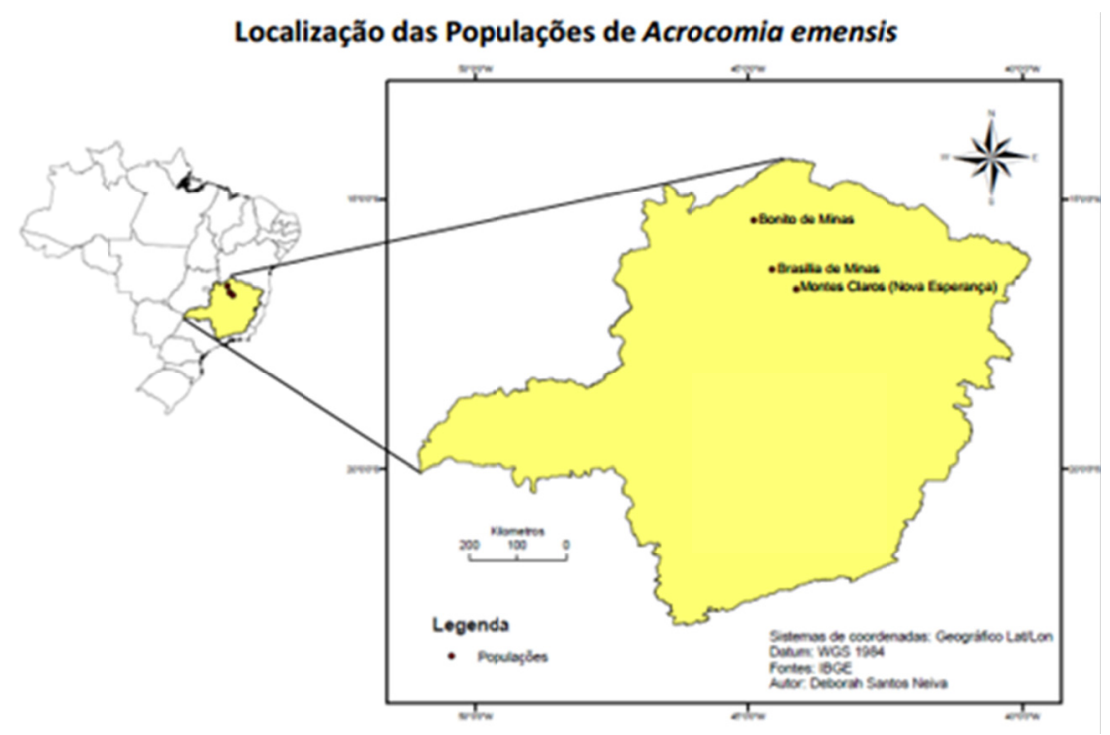

Figure 1. Geographical location of the natural populations of A. emensis

\subsection{Oil Extraction}

The almonds of A. emensis were crushed before pressing, which occurred in two types of cold mechanical presses, to verify which method provided the highest yield. The almonds of $A$. emensis from the population of Bonito de Minas were selected for extraction with walrus type press/bench vise. The almonds of Brasilia de Minas and Montes Claros were processed in a 15 ton manual hydraulic press (Skay).

\subsection{Gas Chromatography}

The analysis were performed on an HP7820A Gas Chromatograph (Agilent) equipped with a flame ionization detector. Data Acquisition Program EZChrom Elite Compact (Agilent). An HP-INNOWax (HP) $15 \mathrm{~m} \times 0.25 \mathrm{~mm}$ $\times 0.20 \mu \mathrm{m}$ column with temperature gradient: $70^{\circ} \mathrm{C}, 0 \mathrm{~min}, 7^{\circ} \mathrm{C} / \mathrm{min}$ to $240{ }^{\circ} \mathrm{C}$ was used; Injector (split of $1 / 50$ ) at $250{ }^{\circ} \mathrm{C}$ and detector at $260{ }^{\circ} \mathrm{C}$. Hydrogen as entrainment gas $(3 \mathrm{~mL} / \mathrm{min})$ and injection volume of $1 \mu \mathrm{L}$. Identification of peaks was done by comparison to FAME C14-C22 methylated fatty acid standards (Supelco cat no 18917).

\subsection{Physico-Chemical Analysis}

The analyses were carried out with oil from the three origins, following the methodologies of the American Oil Chemists Society (AOCS, 2012) for the analyses of acidity index, peroxides, refraction, ashes and relative 
density. To evaluation, the moisture and volatile material and viscosity were used methodologies of the Adolfo Lutz Institute (IAL, 2008).

The exception was the iodine index that was calculated based on the composition of fatty acids with unsaturated bonds and in the percentages in the composition of the oil, obtained by gas chromatography analysis, using equation 1 (Knothe, 2002).

$$
I I_{\text {oil }}=\Sigma 100 \frac{-A f \times 253.81 \times d b}{M W F}
$$

Where, $I I=$ iodine index; $d b=$ number of unsaturated bonds of the fatty acid; $M W F=$ molecular weight of the fatty acid; $253.81=$ weight of two iodine atoms which are theoretically added to a double bond and $A f=$ percentage of the fatty acid in the composition.

\section{Results and Discussions}

\subsection{Extraction of the Oil}

The almonds used to extract the crude oil of A. emensis had a dry mass weight ranging from $0.82 \mathrm{~g}( \pm 4.03)$ to $1.68 \mathrm{~g}( \pm 4.42)$, being these values for the populations of Brasília de Minas and Bonito de Minas, respectively. The almond of the A. emensis is small and difficult to remove from the endocarp, which makes that the removal without damage be a difficult task. This was also observed in the almond of Jerivá, which has an average weight of $0.23 \mathrm{~g}$, which is lower than the weight measured for the almonds of A. emensis (Goudel et al., 2013).

The extraction of the oil with the walrus type press (Bonito de Minas population) was more laborious, compared to the hydraulic press, but with the best yield (18\%). Extraction in hydraulic press (populations of Brasília de Minas and Montes Claros) was faster, but the extraction yield was lower, being that oil yield of the population of Brasília de Minas was $11.75 \%$ and of the population of Montes Claros was $10.60 \%$. With that, it was observed that the extraction using the walrus type press allowed a greater use of the almonds of $A$. emensis.

\subsection{Chromatographic Analysis}

The oils of A. emensis have eight fatty acids (Figure 2), which have between 12 and 18 carbons in their chains, as can be observed in the chromatograms.

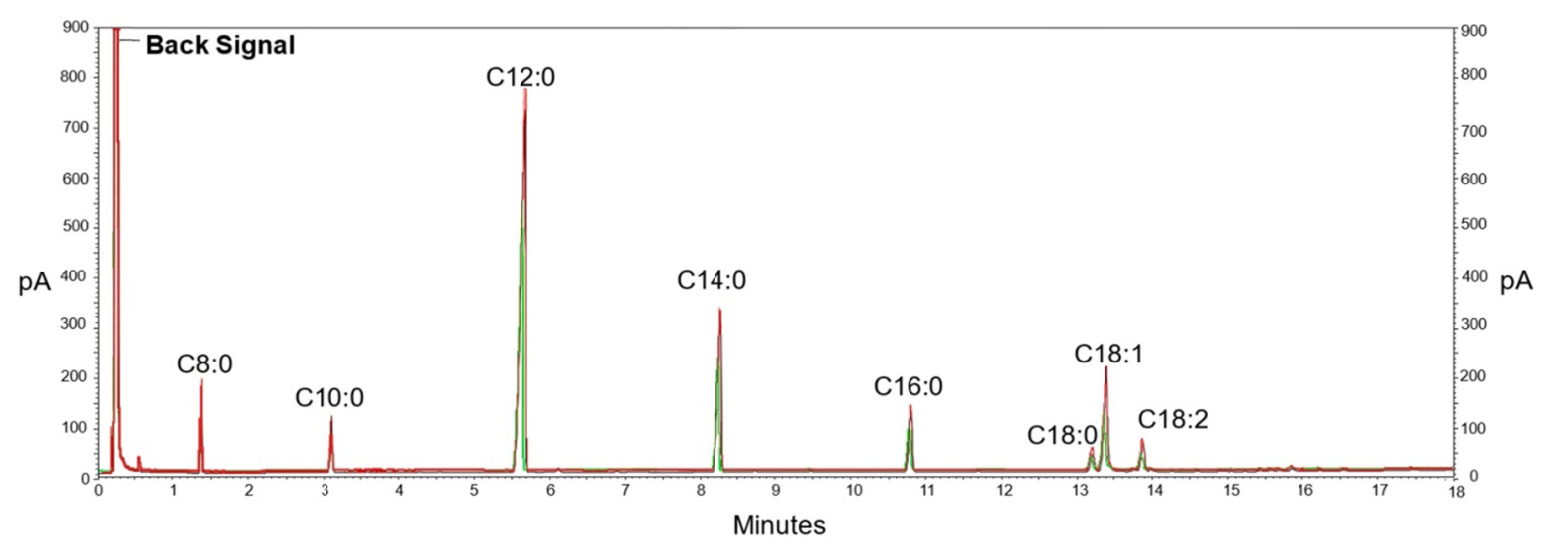

Figure 2.Chromatograms of the oil samples from the three populations of $A$. emensis (black = Bonito de Minas; red $=$ Brasília de Minas and green $=$ Montes Claros $)$

The amounts of these acids varied little among the three populations, as can be seen in Table 1 . 
Table 1. Fatty acids of oils of species of the family Arecaceae

\begin{tabular}{|c|c|c|c|c|c|c|c|c|c|}
\hline \multirow[b]{2}{*}{ Oil } & \multicolumn{9}{|c|}{ Fatty acids (\%) } \\
\hline & $\begin{array}{l}\text { Caprylic } \\
(\mathrm{C} 8: 0)\end{array}$ & $\begin{array}{l}\text { Capric } \\
\text { (C10:0) }\end{array}$ & $\begin{array}{l}\text { Lauric } \\
\text { (C12:0) }\end{array}$ & $\begin{array}{l}\text { Myristic } \\
(\mathrm{C} 14: 0)\end{array}$ & $\begin{array}{l}\text { Palmitic } \\
\text { (C16:0) }\end{array}$ & $\begin{array}{l}\text { Stearic } \\
(\mathrm{C} 18: 0)\end{array}$ & $\begin{array}{l}\text { Oleic } \\
\text { (C18:1) }\end{array}$ & $\begin{array}{l}\text { Linoleic } \\
(\mathrm{C} 18: 2)\end{array}$ & Ref. \\
\hline A. emensis & 3.48 & 3.08 & 49.82 & 17.22 & 6.52 & 2.15 & 10.68 & 2.97 & (1) \\
\hline A. emensis & 3.35 & 3.11 & 50.57 & 16.35 & 6.01 & 2.42 & 11.77 & 3.39 & (2) \\
\hline A. emensis & 2.82 & 2.66 & 51.04 & 17.51 & 6.06 & 2.02 & 11.81 & 3.58 & (3) \\
\hline \multirow[t]{3}{*}{ Babaçú } & 5.0 & 6.0 & 44.0 & 17.0 & 8.0 & 4.5 & 14.0 & 2.0 & $(\overline{4})$ \\
\hline & 4.74 & 5.17 & 44.96 & 16.91 & 9.7 & 11.44 & 7.0 & - & (5) \\
\hline & 5.03 & 9.18 & 46.89 & 16.95 & 7.98 & 2.38 & 13.54 & 1.34 & (6) \\
\hline \multirow[t]{2}{*}{ Buriti } & - & - & - & 0.5 & 19.2 & 1.3 & 65.6 & 4.9 & (7) \\
\hline & - & - & 0.1 & 0.1 & 18.75 & 1.35 & 75.5 & 2.15 & (8) \\
\hline Tucumã & 2.03 & 1.83 & 51.42 & 26.09 & 5.55 & 2.36 & 5.97 & 2.09 & ${ }^{-(\overline{9})}-$ \\
\hline \multirow[t]{2}{*}{ Palma } & - & - & 0.05 & 1.14 & 45.24 & 4.13 & 37.23 & 10.6 & ${ }^{-}(\overline{1} \overline{0})$ \\
\hline & - & - & - & - & 45.6 & 3.2 & 38.5 & 10.5 & (11) \\
\hline Macaúba & 3.67 & 2.79 & 32.58 & 9.21 & 8.25 & 2.24 & 36.27 & 3.82 & $-\overline{1} \overline{2})^{--}$ \\
\hline Jerivá & 6.64 & 5.69 & 33.13 & 9.81 & 8.24 & 3.32 & 27.81 & 4.19 & ${ }^{-}(\overline{1} \overline{2})^{--}$ \\
\hline
\end{tabular}

Note. ${ }^{(1)}$ Bonito de Minas, ${ }^{(2)}$ Brasília de Minas, ${ }^{(3)}$ Montes Claros. References: ${ }^{(4)}$ Lima et al. $(2007) ;{ }^{(5)}$ Machado et al. (2006); ${ }^{(6)}$ Santos et al. (2013); ${ }^{(7)}$ Speranza et al. (2016); ${ }^{(8)}$ Rodrigues et al. (2010); ${ }^{(9)}$ Barbosa et al. (2009); ${ }^{(10)}$ Sotero et al. (2008); ${ }^{(11)}$ Esteban et al. (2012); ${ }^{(12)}$ Coimbra and Jorge (2012).

The fatty acid found in greater quantity in the three oils is lauric acid. This acid is also found in large quantitiy in the Babaçu almond oils (from $44 \%$ to $46.89 \%$ ), Tucumã (51.42\%), Macaúba (32.58\%) and Jerivá (33.13\%) (Table 2). Oils that have a predominance of this acid are interesting for the cosmetics industry and biofuels, due to this acid to confer excellent physico-chemical characteristics to the oil, and in the case of biodiesel production, this fact favors higher yield (González-Perez et al., 2012).

The myristic acid is second most found in A. emensis oils (17.51\%, 16.35\%, and $17.22 \%)$, being also the second most found in Babaçu oils (between 16.91\% and 17.0\%) and Tucumã (26.09\%) as can be seen in Table 1. The oleic acid is third most prevalent in A. emensis oils $(10.68 \%, 11.77 \%$ and $11.81 \%)$. This acid is the majority in the oils of Buriti (between $65.6 \%$ and $75.5 \%$ ) and Macaúba (36.27\%). It is also present in Babaçu oils (between $7 \%$ and $14 \%$ ), Palma (37.23\% and 38.5\%) and Jerivá (27.81\%) (Table 1). The palmitic acid is fourth most found in A. emensis oils $(6.01 \%, 6.06 \%$ and $6.52 \%)$ and in the palm oil is the most prevalent fatty acid (between $45.24 \%$ and $45.6 \%$ ), as can be seen in Table 1 .

\subsection{Physico-Chemical Characterization of Oil}

There are studies that demonstrate the potential of several species of the Arecaceae family for biodiesel production (Table 2).

Table 2. Indices of acidity, peroxides, iodine and moisture of family species oils

\begin{tabular}{lllll}
\hline Species & Acidity $\left(\mathrm{mg} \mathrm{KOH} \mathrm{g}^{-1}\right)$ & Peróxides $\left(\mathrm{meq} \mathrm{Kg}^{-1}\right)$ & Iodine $\left(\mathrm{cg} \mathrm{I}_{2} \mathrm{~g}^{-1}\right)$ & Moisture $(\%)$ \\
\hline A.emensis $^{1}$ & $15.88( \pm 1.08)$ & $14.54( \pm 0.45)$ & 15.74 & $0.178( \pm 0.13)$ \\
A.emensis $^{2}$ & $22.36( \pm 0.43)$ & $15.07( \pm 1.06)$ & 17.57 & $0.589( \pm 0.45)$ \\
A.emensis $^{3}$ & $16.04( \pm 0.54)$ & $12.32( \pm 1.27)$ & 17.97 & $0.499( \pm 0.39)$ \\
Babaçú $_{\text {Palma }}$ & $3.75^{(4)} ; 0.505^{(5)}$ & $0.4^{(4)} ; 0^{(6)}$ & $17.3^{(4)}$ & $0.17^{(4)}$ \\
Tucumã & $11.6^{(7)}$ & $0.6-2.19^{(8)}$ & $50.48^{(9)}$ & - \\
Buriti & $37.5^{(10)} ; 1.9^{(11)}$ & $13.9^{(10)} ; 6.89^{(11)}$ & $220^{(10)}$ & - \\
Macaúba & $5.22^{(12)} ; 1.59^{(11)}$ & $4.61^{(12)} ; 7.49^{(11)}$ & $66.6^{(12)}$ & $0.1^{(12)}$
\end{tabular}

Note. ${ }^{1}$ Bonito de Minas, ${ }^{2}$ Brasília de Minas, ${ }^{3}$ Montes Claros. References: ${ }^{(4)}$ Luz et al. $(2011) ;{ }^{(5)}$ Lima et al. (2007); ${ }^{(6)}$ Machado et al. (2006); ${ }^{(7)}$ Oliveira et al. (2013); ${ }^{(8)}$ Almeida et al. $(2013) ;{ }^{(9)}$ Sotero et al. (2008); ${ }^{(10)}$ Barbosa et al. (2009); ${ }^{(11)}$ Santos et al. (2013); ${ }^{(12)}$ Jacobo et al. (2009); ${ }^{(13)}$ Cesar et al. (2015). 
The oil of A. emensis had an acid index of $15.88 \mathrm{mg} \mathrm{KOH} \mathrm{g}^{-1}, 16.04 \mathrm{mg} \mathrm{KOH} \mathrm{g}^{-1}$ and $22.36 \mathrm{mg} \mathrm{KOH} \mathrm{g}^{-1}$ for the populations of Bonito de Minas, Montes Claros and Brasília de Minas, respectively (Table 3). These values were higher than those reported for the oils: Babaçu $\left(3.75 \mathrm{mg} \mathrm{KOH} \mathrm{g}^{-1}\right.$ and $\left.0.50 \mathrm{mg} \mathrm{KOH} \mathrm{g}^{-1}\right)$, Palma (11.6 mg KOH $\left.\mathrm{g}^{-1}\right)$, Buriti $\left(5,22 \mathrm{mg} \mathrm{KOH} \mathrm{g}^{-1}\right.$ and $\left.1.5 \mathrm{mg} \mathrm{KOH} \mathrm{g}^{-1}\right)$ and Macaúba $\left(5.61 \mathrm{mg} \mathrm{KOH} \mathrm{g}^{-1}\right)$. However, when we compare the A. emensis oils with the Tucumã oil $\left(37.5 \mathrm{mg} \mathrm{KOH} \mathrm{g}^{-1}\right.$ and $\left.1.9 \mathrm{mg} \mathrm{KOH} \mathrm{g}^{-1}\right)$ we noticed that the acid value of $A$. emensis oil is intermediate.

The oil extracted from the almonds of the population of Brasília de Minas (22.36 $\left.\mathrm{mg} \mathrm{KOH} \mathrm{g}^{-1}\right)$ had the highest acidity value. This result can be due to possible degradation of the almonds, due to the time elapsed between the collection and the extraction of the oil, this can be applied to the other oils. In this way, the selection of operating conditions (storage and time) reduces changes and is important for obtaining a good quality product.

The values of peroxides for the oils of the populations of Brasília de Minas (15.07 meq kg-1 $)$, Bonito de Minas (14.54 meq kg $\mathrm{g}^{-1}$ ) and Montes Claros (12.32 meq kg$)$ were higher than the values reported in the literature for other oils of the Arecaceae family species: Babaçu $\left(0\right.$ and 0.4 meq kg $\left.{ }^{-1}\right),\left(0\right.$ and $\left.0.4 \mathrm{meq} \mathrm{kg}^{-1}\right)$, Palma $(0.6$ and

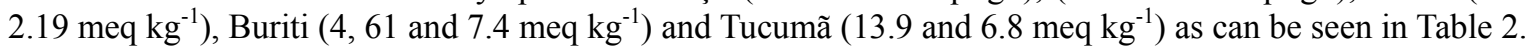

The moisture of the oil of the almonds in the population of Brasília de Minas $(0.589 \%)$ was higher than the value of samples from Montes Claros $(0.499 \%)$ and Bonito de Minas $(0.178 \%)$. These results corroborate with the biometric analyzes, where the population of Brasília de Minas also had a higher percentage of moisture in the epicarp, mesocarp and seed. The moisture in the Bonito de Minas oil sample was similar to the values reported for Babaçu $(0.17 \%)$ and Buriti $(0.1 \%)$ as can be seen in Table 2. The moisture value confirms the analysis of acidity and peroxide, because in both, the oil of the population from Brasília de Minas obtained a higher value in relation to the other populations, demonstrating that moisture is one of the factors that influence on this parameter.

The iodine index of A. emensis oils varied little among the three populations. In the oil from Montes Claros (17.97 $\mathrm{cg} \mathrm{I}_{2} \mathrm{~g}^{-1}$ oil), a value very close to that of Brasília de Minas (17.57 $\mathrm{cg} \mathrm{I}_{2} \mathrm{~g}^{-1}$ oil) was observed. On the other hand, the oil from the population of Bonito de Minas $\left(15.74 \mathrm{cg} \mathrm{I}_{2} \mathrm{~g}^{-1}\right.$ oil $)$ had the lowest iodine value. In spite of this variation is possible to verify that these values are similar to the one mentioned for the oil of Babaçu (17.3 $\mathrm{cg} \mathrm{I}_{2} \mathrm{~g}^{-1}$ oil), and are inferior to those reported for oils of Palma (50.48 $\mathrm{cg} \mathrm{I}_{2} \mathrm{~g}^{-1}$ oil), Buriti (66.6 $\mathrm{cg} \mathrm{I}_{2} \mathrm{~g} \mathrm{~g}^{-1}$ oil) and Tucumã (220 cg I $\mathrm{g} \mathrm{g}^{-1}$ oil) (Table 2).

The degree of oil insaturation is what determines the iodine index. Soon after analyzing the fatty acid composition (Table 1) it is possible to verify that the oil of the population of Montes Claros, which had a higher iodine value, is the one with the highest amount of oleic fatty acids (11.81\%) and linoleic acid (3.58\%). In the locality Brasília de Minas, where was observed iodine value lower than Montes Claros, it has oleic acid (11.77\%) and linoleic acid (3.39\%) in intermediate amounts among the three populations. On the other hand, the oil from the locality Bonito de Minas has the lowest amounts of oleic acid (10.68\%) and linoleic acid (2.97\%), which reflects a lower iodine value.

The oil extracted from the population of Bonito de Minas was the one that obtained the highest viscosity value $\left(67.89 \mathrm{~mm}^{2} \mathrm{~s}^{-1}\right)$, followed by Brasília de Minas $\left(60.70 \mathrm{~mm}^{2} \mathrm{~s}^{-1}\right)$ and Montes Claros $\left(54,60 \mathrm{~mm}^{2} \mathrm{~s}^{-1}\right)$. These values are higher than those reported for Babaçu oil $\left(34.84 \mathrm{~mm}^{2} \mathrm{~s}^{-1}\right)$ and Macaúba oil $\left(4.20 \mathrm{~mm}^{2} \mathrm{~s}^{-1}\right)$, however are lower than the value of palm oil $\left(79.7 \mathrm{~mm}^{2} \mathrm{~s}^{-1}\right)$ (Table 3$)$.

Table 3. Refraction, viscosity, density and ash of oils of species of the family Arecaceae

\begin{tabular}{lllll}
\hline Species & Refraction $(\mathrm{nD})$ & Viscosity $\left(\mathrm{mm}^{2} \mathrm{~s}^{-1}\right)$ & Density $\left(\mathrm{g} \mathrm{cm}^{-3}\right)$ & Ash $(\%)$ \\
\hline A. emensis $^{1}$ & 1.455 & $67.89( \pm 2.70)$ & $0.937( \pm 0.00)$ & $0.622( \pm 0.13)$ \\
A. emensis $^{2}$ & 1.456 & $60.70( \pm 0.98)$ & $0.882( \pm 0.00)$ & $0.909( \pm 0.46)$ \\
A. emensis $^{3}$ & 1.458 & $54.60( \pm 3.62)$ & $0.884( \pm 0.00)$ & $0.498( \pm 0.18)$ \\
Babaçu & $1.448^{(4)}$ & $34.84^{(5)}$ & $0.914^{(6)} ; 0.914^{(4)}$ & $0.03^{(7)}$ \\
Palma & $1.460^{(8)}$ & $79.7^{(9)}$ & $0.9151^{(8)} ; 0.917^{(9)}$ & $0.01^{(7)}$ \\
Tucumã & - & - & $0.8889^{(10)}$ & - \\
Buriti & $1.466^{(11)}$ & - & $0.9097^{(11)}$ & - \\
Macaúba $^{(12)}$ & $4.20^{(12)}$ & $0.9205^{(12)}$ & -
\end{tabular}

Note. ${ }^{1}$ Bonito de Minas, ${ }^{2}$ Brasília de Minas, ${ }^{3}$ Montes Claros. References: ${ }^{(4)}$ Machado et al. (2006); ${ }^{(5)}$ Nascimento et al. (2009); ${ }^{(6)}$ Luz et al. (2011); ${ }^{(7)}$ Costa Neto et al. $(2000) ;{ }^{(8)}$ Sotero et al. (2008); ${ }^{(9)}$ Siddique et al. (2010); ${ }^{(10)}$ Barbosa et al. (2009); ${ }^{(11)}$ Jacobo et al. (2009); ${ }^{(12)}$ Cesar et al. (2015). 
The viscosity of oils increases with the length of the chains of the fatty acids that compose it and decreases with the increase of the degree of insaturation. As can be seen in Table 1, fatty acids that have the largest chain size are also the only ones that have insaturations. Thus it can be inferred that the oil of Bonito de Minas has higher viscosity among the oil of the three populations due to the lower amount of oleic (16.68\%) and linoleic (2.97\%) unsaturated fatty acids. On the other hand, the oil of the Montes Claros population had a lower viscosity value due to the higher amount of oleic acid (11.81\%) and linoleic acid (3.58\%). Moreover, the oil of the locality Brasília de Minas has intermediate amounts of oleic acids (11.77\%) and linoleic acids (3.39\%) which legitimates with the viscosity measured for the oil of that locality.

The density values of the oils from the populations of Brasilia de Minas $\left(0.882 \mathrm{~g} \mathrm{~mL}^{-1}\right)$ and Montes Claros $\left(0.884 \mathrm{~g} \mathrm{~mL}^{-1}\right)$ were similar. However, the oil of the population of Bonito de Minas $\left(0.937 \mathrm{~g} \mathrm{~mL}^{-1}\right)$ had a higher value than the other populations. When compared to the oils of other species of the family Arecaceae, it is possible to observe that the values are close, as can be seen in Table 3.

The oil ash index of the population of Brasília de Minas (0.909\%) was higher than the value measured for the populations of Bonito de Minas $(0.622 \%)$ and Montes Claros $(0.488 \%)$. These values are higher than those determined for palm $(0.01 \%)$ and Babaçu $(0.03 \%)$ oils (Table 3$)$.

The refractive index increases with the length of the hydrocarbon chain and with the degree of insaturation of the fatty acids constituting the triglycerides. It can still vary with the presence of oxidized compounds and polymers and with heat treatment, so it will be characteristic for each type of oil (Santos \& Vieira, 2013). The refractive index was similar for the oils of the populations of Bonito de Minas (1.455 nD), Brasília de Minas (1.456 nD) and Montes Claros (1.458 nD). This value is close to that verified for oils from other palms such as Babaçu $(1.448 \mathrm{nD})$, Palm $(1.460 \mathrm{nD})$, Buriti $(1.466 \mathrm{nD})$ and Macaúba $(1.451 \mathrm{nD})$ as can be seen in Table 3 .

\section{Conclusions}

The physico-chemical characteristics of the oils extracted from the almonds of these fruits of A. emensis varied among the analyzed populations. Being that these differences may be due to genetic factors and environmental conditions, since the availability of water, temperature and soil can influence the quality of the oil. It can be concluded that the oil of $A$. emensis has similar characteristics to other oils of species of the family Arecaceae. Therefore, it can be inferred that this oil has potential for industrial use. However, it is important to improve the extraction of the oil to obtain a higher yield and a better use of the raw material. It is also necessary to work the storage of the fruits and almonds to obtain oil with acidity indexes and peroxides lower.

\section{Acknowledgements}

We thank the Foundation for Research Support of Minas Gerais.

\section{References}

Almeida, D. T. de, Nunes, I. L., Conde, P. L., Rosa, R. P. S., Rogerio, W. F., \& Machado, E. R. (2013). A qualityassessment of crude palm oil marketed in Bahia, Brazil. Grasas y Aceites, 64, 387-394. https://doi.org/10.3989/gya.118412

AOAC (Association of Official Analytical Chemistry). (2012). Official methods of analyses (19th ed.). Gaithersburg.

Barbosa, B. S., Koolen, H. H. F., Barreto, A. C., Silva, J. D., Figliuolo, R., \& Nunomura, S. M. (2009). Aproveitamento do óleo das amêndoas de Tucumã do amazonas na produção de biodiesel. Acta Amazônica, 39, 371-376. https://doi.org/10.1590/S0044-59672009000200015

César, A. S., Almeida, F. A., Souza, R. P., Silva, G. C., \& Atabani, A. E. (2015). The prospects of using Acrocomia aculeata (macaúba) a non-edible biodiesel feedstock in Brazil. Renewable and Sustainable Energy Reviews, 49, 1213-1220. https://doi.org/10.1016/j.rser.2015.04.125

Coimbra, M. C., \& Jorge, N. (2012). Fatty acids and bioactive compounds of the pulps and kernels of Brazilian palm species, guariroba (Syagrus oleraces), jerivá (Syagrus romanzoffiana) and macaúba (Acrocomia aculeata). Journal of the Science of Food and Agriculture, 92, 679-684. https://doi.org/10.1002/jsfa.4630

Costa Neto, P. R., Rossi, L. F. S., Zagonel, G. F., \& Ramos, L. P. (2000). Produção de biocombustível alternativo ao óleo diesel através da transesterificação de óleo de soja usado em frituras. Química Nova, 23, 531-537. https://doi.org/10.1590/S0100-40422000000400017 
Esteban, B., Riba, J. R., Baquero, G., Rius, A., \& Puig, R. (2012). Temperature dependence of density and viscosity of vegetable oils. Biomass and Bioenergy, 42, 164-171. https://doi.org/10.1016/j.biombioe.2012. 03.007

González-Pérez, S. E., Coelho-Ferreira, M., Robert, P., \& Garcéz, C. L. L. (2012). Conhecimento e usos do babaçu (Attalea speciosa Mart. E Attalea eichleri (Drude) A. J. Hend.) entre os Mebêngôkre-Kayapó da Terra Indígena Las Casas, estado do Pará, Brasil. Acta Botanica Brasilica, 26, 295-308. https://doi.org/ 10.1590/S0102-33062012000200007

Goudel, F., Shibata, M., Coelho, C. M. M., \& Miller, P. R. M. (2013). Fruit biometry and seed germination of Syagrus romanzoffiana (Cham.) Glassm. Acta Botanica Brasilica, 27, 147-154. https://oi.org/10.1590/ S0102-33062013000100015

IAL (Instituto Adolfo Lutz). (2008). Métodos Físico-Químicos para Análise de Alimentos (1st ed. Digital). Retrieved June 15, 2014, from http://www.ial.sp.gov.br/index.php?option=com_remository\&Itemid=0\& func $=$ select\&id $=1$ \&orderby $=1 \&$ page $=1$

Jacobo, F. Q., Rojas, M. A., Reyes, G. I., Pino, E. L., \& Chagman, G. P. (2009). Caracterización de aceites, tortas y harinas de frutos de Ungurahui (Jessenia polycarpa) Yaguaje (Mauritia flexuosa L.) de la amazonía peruana. Revista de la Sociedad Química del Perú, 75, 243-253.

Knothe, G. (2002). Structure Indices in FA Chemistry. How Relevant Is the Iodine Value? Journal of the American Oil Chemists'Society, 79, 847-854. https://doi.org/10.1007/s11746-002-0569-4

Lima, J. R. O., Silva, R. B., Silva, C. C. M., Santos, L. S. S., Santos Jr, J. R., Moura, E. M., \& Moura, C. V. R. (2007). Biodiesel de babaçu (Orbignya sp.) obtido por via etanólica. Química Nova, 30, 600-603. https://doi.org/10.1590/S0100-40422007000300019

Lorenzi, H. (2010). Flora Brasileira (Arecaceae) (p. 368). Instituto Plantarum. Nova Odessa.

Luz, D. A., Machado, K. R. G., Pinheiro, R. S., Maciel, A. P., Souza, A. G., \& Silva, F. C. (2011). Studies of physico-chemical crude babassu oil (Orbignya phalerata Mart.) and a byproduct of the degumming step of the refining process. Caderno Pesquisa, 18, 19-22.

Machado, G. C., Chaves, J. B. P. \& Antoniassi, R. (2006). Composição em ácidos graxos e caracterização física e química de óleos hidrogenados de coco babaçu. Ceres, 53, 463-470.

Manfio, C. E., Motoike, S. Y., Santos, C. E. M., Pimentel, L. D., Queiroz, V., \& Sato, A. Y. (2011). Repetibilidade em características biométricas do fruto de macaúba. Ciência Rural, 41, 70-76. https://doi.org/10.1590/S0103-84782011000100012

Nascimento, U. M., Vasconcelos, A. C. S., \& Azevedo, E. B. (2009). Otimização da produção de biodiesel a partir de óleo de coco babaçu com aquecimento por microondas. Eclética Química, 34, 37-48. https://doi.org/10.1590/S0100-46702009000400004

No, S. Y. (2011). Inedible vegetable oils and their derivatives for alternative diesel fuels in CI engines: A review. Renewable and Sustainable Energy Reviews, 15, 131-149. https://doi.org/10.1016/j.rser.2010.08.012

Oliveira, D. M., Ongaratto, D. P., Fontoura, L. A. M., Naciuk, F. F., Santos, V. O. B., Kunz, J. D., ... Samios, D. (2013). Obtenção de biodiesel por transesterificação em dois estágios e sua caracterização por cromatografia gasosa: Óleos e gorduras em laboratório de química orgânica. Química Nova, 36, 734-737. https://doi.org/10.1590/S0100-40422013000500021

Rodrigues, A. M. C., Darnet, S., \& Silva, L. H. M. (2010). Fatty Acid Profiles and Tocopherol Contents of Buriti (Mauritia flexuosa), Patawa (Oenocarpus bataua), Tucuma (Astrocaryum vulgare), Mari (Poraqueiba paraensis) and Inaja (Maximiliana maripa) Fruits. Journal of the Brazilian Chemical Society, 21, 2000-2010. https://doi.org/10.1590/S0103-50532010001000028

Santos, M. F. G., Marmesat, S., Brito, E. S., Alves, R. E., \& Dobarganes, M. C. (2013). Major components in oils obtained from Amazonian palm fruits. Grasasy Aceites, 64, 328-334. https://doi.org/10.3989/gya.023513

Santos, R. C. R., Vieira, R. B., \& Valentini, A. (2013). Monitoring the conversion of soybean oil to methyl or ethyl esters using the refractive index with correlation gas chromatography. Microchemical Journal, 109, 46-50. https://doi.org/10.1016/j.microc.2012.05.001

Siddique, B. M., Ahmad, A., Ibrahim, M. H., Hena, S., Rafatullahb, M., \& Omar, A. K. M. (2010). Physico-chemical properties of blends of palm olein with other vegetable oils. Grasasy Aceites, 61, 423-429. https://doi.org/10.3989/gya.010710 
Sotero, D. G., Águila, J. S., Ramírez, R. S., Reáteguil, G. C., Ríos, J. A. S., Solís, V. S., Torres, R. P., \& Mancini Filho, J. (2008). Fraccionamiento e interesterificacion del aceite de palma (Elaeis guineensis) cultivado en la amazonia peruana. Grasasy Aceites, 59, 104-109. https://doi.org/10.3989/gya.2008.v59.i2.497

Speranza, P., Falcão, A. O., Macedo, J. A., Silva, L. H. M., Rodrigues, A. M. C., \& Macedo, G. A. (2016). Amazonian Buriti oil: chemical characterization and antioxidant potential. Grasas y Aceites, 67, e135. https://doi.org/10.3989/gya.0622152

\section{Copyrights}

Copyright for this article is retained by the author(s), with first publication rights granted to the journal.

This is an open-access article distributed under the terms and conditions of the Creative Commons Attribution license (http://creativecommons.org/licenses/by/4.0/). 